\section{The Ifellowship Address}

ON THE

\section{NEED) FOR CO-OPERATIVE THOU('H'T' IN SURGICAL ORGANI\%A'IION. \\ DELIVERF D AT}

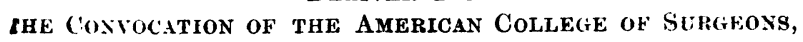
Philadelphia, OCtober 28Th, 1921,

BY

Sik llARLD J. STILES, K.B.E., M.B., F.H.C.S., REGIUS PHOYESSOR OF CLINICAL SURGERY, CNIVERSITY OF FDINIUURH.

Mr first duty is to thank the President and Regents of the College for so kindly inviting mo to take part in the Clinic Congress. For three years in succession I had receivel an invitation, and gladly wonk $I$ have accepted, but in view of my recent appointment to the chair of Clinicul Surgery in the University of Edinburgh I did not fecl justified in applying to the Univcrsity Court for leave of absence. It so happened this year that the Congress of the: (niversities of the British Empire was holding its mectings in Great Britain when I received your invita. tion to be a guest at the Congress. One of the speakers, Professor 'T. J. Wilson of Cainbridge, declared that p:o. fessor's should not merely be given leave of absence but slionld rather be liunted out of their chairs for the health of their own souls and of those committed to their care. Those words so emboldened me that I accepled your invitation on my own initiative without waiting for the perinission which the university granted me later.

America has already been more than generous in making me an honorary member of the Americau Medical Association and of her three chief Surgical Associations. 'To occupy a place on the roll of Honor.ry Fellows of the College of Surgeons of America is an honour of which am intencely and genuinely proud, and it is one which $I$ and my descendants will treasure for all time as a crowning reward for my surgical endeavor 3 . I am only too conscious that the honour is out of all proportion to my very bumble achievements; rather do I regard it as a gracious compliment to tire famous university to which I have the honour to belong, and as a venerous recognition of the great traditions of the survical school from which I have descended. I am particularly proud that the - honour you have just conferred on me should have been received in the city of Philadelphia, the birthplace not only of the oldest medical schuol in the United States, but also of that one which I believe has more Ediuburgh blood in its veins than can be traced in the pedigree even of Columbia and Harvard.

The war of the Revolution was the making of Morgan and Shippen, two of the greatest pioneer surgeons of the oighteenth century, both Philadelphians and both Edinburgh graduates. Physick, who was professor of surgery in the Ciniversity of Philadelphia in the early part of last century. and who has often been spoken of as the father of American surgery, was also educated in E linburgh. Then, again, we have Samuel $G$ oss, said by some to be the father of modern American surgery. He played the same part in Philadelphia that Syme did in Edinburgh. They had much in common: both were good anatomists and pathologists as well as great surgeons; both were great diagnosticians and great teachers, and both had the art of inspiring and of retaining the affection of their pupils. Althonglı (iross was not an Edinburgh graduate, he visited Edinburgh when Syme and Simpson were at the height of their fane.

Gross has always occupied a warm place in my heart, particularly on account of his admiration for the work of Sir Astley Cooper. Dr. Finney. in one of his admirable addresses, savs: "Teachers in medical schools should not only instruct their pupils but should instil into them by precept and example the right spirit towards their profession and the right attitude towards their patients"- and this Sir Astley Cooper surely did. My grandfather, who lived to the age of 96, wrote of his great master, Cooper:

"It would be an act of ingratitude did I omit to pay a tribute of respect to the memory of $\mathrm{my}$ distinguished anatomical an ourgical teacher, sir Astley Cooper. He did not owe his dis tinction to exalted rank or to privileges attached to high birth but rose by the honourable exertion of his native energies, and but rose by the honourable exertion of his native energies, and ultimately attained the most exalted pre-eminence; indeed became one of the most illustrious surgeons that ever adorned
the science he professed. To Sir Astley Cooper I am indebted, the science he professed. To Sir Astley Cooper I am indebted,
more than to any other man that ever lived, not only for the greater share of anatomicil and surgical knowledge I possess, but for the privilege of witnessing in him the enthusiasm which filled his soul with an ardour and love of his profession, which incited in me a noble emulation to imitate his pra sewcrthy example. He stimulated me to exertion--stimulated me in the acquirement of knowledge."

Incidentally, I may say that it was through the references in my grandfather's antobiography to Sir Astley Cooper that I myself became fired with the ambitiou to become a surgeon. Gross, in his antobiograplsy, said :

"I learned my first lessons in surgery from Sir Astley Cooper's lectures, reprinted in Philadelphia soon aft $x^{\circ} I$ began the study of medicine. Every student should read them, for they abound in good sense and somil practical knowle: Ige."

The same remaik would apply to Syme s Principles of Surgery. On visitiug St. Paul's Cathedral Gross expressed his delight at seeing there a statue to Sir Astley Cooper, but took the occasion to deplore the absence of similas memorials in America to inspire youth with ambition-a grievance which the American Surgical Association so wi ely and generously removed after the death of Gross by erecting in Washinoton a statue to his memory. Syme Lister, Gioss, Keene, Murphy, and many others have had the same inspiring influence as Cooper over their pupils.

The Eningurgh School of Surgery.

The Edinburgh School of Surgery, to which you have paid a tribute in honouring one of its teachers, dates back to 1505, when the Town Council granted the Corporation of Surgeons and Barbers permission to dissect the body of one condenued man in the year. The English Company of Barber-Surgeons did not receive their charter until thirty-five year's later. The oldest minute-book in the possession of the Edinburgh College of Surgeons contans on its first page, a piayer by the famous Scottish reformei. Jolnn Knox, and I will quote it, as it has since been read by the Secreta:y at the opening of every meeting of the College :

"O eternal frod, and our lovin! and mercifull Father in Christ Jesus, sccmg we are concenit heir to treat upomn thes things that concernis our calling, we bescik thee, 'O lord, to be mercifull to us, and giff us grace to proceid thercintill without malice, grudge, or partialitie; sua that the thing.s ue may do may tend to the glorie of God, the weill of our cocation, and confort of every member of the samen; throu Jesus Christ, our only Lord and Saviour; Amen."

The next step in the evolution of the Edinburgh School consisted in the creation of the museum of the college. which is one of the finest collections in Europe. In 1703 the Incorporation of Surgeons erected an anatomical theatre, and two years later Robert Pliot was appointed fir.t professor of anatomy in the 'Town's ('ollege, which had received its charter from James VI in 1582.

John Monro, a Fellow of the College of Surgeons, whose ambition it was to found a medical school in Edinburgh, sent his son, Alexauder Monro, to study anatomy and surgery in London, Paris, and Leyden. In 1720 Alexander Monro was appointed to the chair of anatomy; a few years later (1725) he transferred his teaching to the University, and the following year saw the establishment of a Medical Faculty. Ot Alexander Monro primuss it can truly be said that he was "the father" of the Edin. burgh Medical School," ancl, although he was more anatomist than surgeon, Edinburgh surgery owes hin an everlasting debt of gratitude for being the moving spirit, along with Lord Provost Drummond, in found. ing the Royal Infirmary, which soon developed into one of the most famous schools of clinical teaching in the wcrld.

Previous to the establishment of a Faculty of Medicine in the Unirersity of Edinburgh anatomy had been taught 
by private lecturers belonging to the Incorporation of Surgeons. These men were really the pioneers of the Edinburgh Extra-mural School.

What is now known as the Old Royal Infirmary, where Lizars, Fergusson, Liston, Syme and Lister did their epoch-making work, was opened in 1741. It contained 228 beds, and a single operating theatre accommodating 200 students.

Before 1833, when Syme became Professor of Olinioal Surgery in the University, the Edinburgh School of Surgery was rendered famous by Benjamin Bell, whose System of Surgery, in six volumes, was translated into French and German, and by the brothers John and Charles Bell, the former a great surgeon-anatomist, and the latter also an epoch-making physiologist, his discovery of the functions of the spinal nerve roots entitling him to rank second only to Harvey. Charles Bell migrated to London, to return to Edinburgh later as Professor of Systematic Surgery. While in London he taught anatomy the well-known Great Windmill Street School, where he accumulated a number of valuable specimens, now in the Museum of the College of Surgeons of Edinbargh. Both he and his brother John were endowed with great artistic talent, and Sir Charles Bell's water-colour drawings of gunshot wounds, the result of his experience at Waterloo, are classical.

The fame of the Edinburgh School of Surgery in the first half of the last century was largely due to the surgeon-anatomists of the extra-mural school. Principal Sir Alexander Grant, in his historical volume entitled The Story of the University, gives full credit to the important part played by the extra-mural lecturers in the evolution of the Edinburgh Medical School, and romarks that

"One of its greatest advantages has been that the University has continued to be surrounded by extra-mural rivals who have kept its professors up to the mark and sometimes eclipsed them, and who have always been in training to fill up the ranks of the University whenever vacancies occurred."

My colleague, $\mathrm{Mr}$. Miles, in his admirable little book on The Edinburgh School of Surgery before Lister, makes the further observation that-

"In another direction, the extra-mural teachers have played an important part in guiding the destinies of the medica ohool. Free from the bonds of statutes and ordinances, they have always been able to lead the way into developing instruction in special branches of knowledge, and many of the fion in special branches of knowledge, and many of the originated in the extra-mural school."

The ohair of Clinical Surgery, which I have now the honour to occupy, was founded by George III in 1803. The first occupant was James Russell, who enjoyed the intimate friendship of Sir Walter Scott. On his resignation Liston and Syme contested the vacancy. The latter was appointed, and became the greatest teacher of his generation. He died in 1870, shortly after his son-in-law, the immortal Lister, who succeeded him, had initiated the new era in surgery.

A few years later Robert Liston accepted the chair of Olinical Surgery at University College Hospital, London. He was perhaps the most famous of all the anatomical surgeons in the Edinburgh school. Before he was appointed to the staff of the Edinbargh Royal Infirmary he was performing, with the assistance of Syme, operations more formidable than those which were undertaken in the

Infirmary. He is well known to us all as the introducer of the transfixion method of amputation, and as being the curgeon who performed the first major operation in London under ether, in 1846; it was an amputation through the thigh. There was a dispute between the time-keepers as to whether it took twenty-five or twenty-eight seconds to remove the limb. The patient was in the operating theatre only five minutes. Liston's remark as the patient was leaving the theatre was, "This Yankee dodge, gentlemen, beats mesmerism hollow."

Lizars, who was appointed professor of surgery in the College of Surgeons of Edinburgh in 1831, is well known in America as being the first surgeon in Great Britain to perform the operation of ovariotomy, which had been introduced by MacDowell. MacDowell had sent a copy of his first paper to his old teacher, John Bell of Edinburgh, who was then ending his days in Italy. The paper came into the hands of Lizars, who was also a pupil of Bell's.
Of all my predecessors, however, the immortal Lister stands out pre-eminent, and I refer to him with the deopest humility, as I am only too consoious of my inability to maintain the great traditions which he created in the Edinburgh School. The very Rev. Dr. Wallace Williamson, Dean of the Thistle and minister of the historic Cathedral of St. Giles in Edinburgh, has con. tributed to the history of medicine a most beautiful and life-like word portraiture of Lister, and I rejoice to think that it will become immortalized by Garrison in his splendid work on the History of Medicine, a volume of immeasurable educational value and one which should occupy a foremost place in the library of every member of our profession. Williamson said :

" Of Joseph Lister's winsome personality, those speak most warmly who knew him best. It was his gentleness, above all, that made him great. His very presence was a spiritual force. Clear-eyed and pure of soul, he cherished from earliest days that love of truth which guided him to the end. His noble
passion for humanity extinguished all thoughts of self and personal fame, impelling him along that path which he steadpersonal fame, impelling him along that path which he steadand bestowed on the world probably the greatest boon which and bestowed on the world probably the greatest boon which
science has been able to win for the physical life of mankind.
Yet greater than his greatest achievement was the man Yet greater than his greatest achievement was the man himself, and the final secret of his greatness was that serene His was the grave and thoughtful conrtesy which bespoke the Christian gentleman and the earnest lover of his kind. Hence we are not surprised to learn how he stirred enthusiasm and moved men to reverence, how he gained such love and affection as rarely falls to a scientific teacher. Behind his acknowledged mastery of his science, his grave and noble face, marked by soft lines of tranquil thought, revealed a soul of singular beauty and sweetness, of high integrity and staingenius, should rise to the lofty beights and achieve great genius, should rise to the

Although the last century saw the end of the purely anatomical era of surgery, I have no hesitation in bringing into the foreground the prominent part which the great surgeon-anatomists of my school have taken in the evolution of surgery. The medical curriculum is now so over. orowded that the medical student, while he may be more spoon-fed with anatomical details, does not acquire the same dissecting-room knowledge of anatomy that was possessed by the student of my day. The dissecting room is the surgeon-probationer's basic laboratory. My advice to all my house-surgeons who wish to take up surgery as their life-work is to go back to the dissecting room and teach practical anatomy for at least one year. This is not only good for himself, for surgery, and for his patients, but it is an advantage also to the dissecting room, as it supplies it with demonstrators who can appreciate and point out the bearing of anatomical details and topographical relations on the practice of surgery.

It has been said that a weak point in the training of the young American surgeon of the present generation is his deficient knowledge of morbid anatomy and morbid histology, and that he too often feels the need of a patho. logist at his elbow in the operating theatre. Personally, I am always gratefui that early in my career I devoted time to the study of surgical pathology. For two years following my house-surgeonship I was a whole-time demonstrator of anatomy, and for the succeeding nine years, during which I taught surgical anatomy, I had oharge of the pathological laboratory in connexion with the chair of systematic surgery then occupied by Professor Ohiene. In this capacity it was my duty to give demon: strations in surgical pathology to his class, and to examine and report upon all material derived from his wards. The surgeon of to-day cannot be regarded as fully trained unless he himself is pathologist enough to be able to assess the significance of the naked-eye and histological appearances of the tissues and organs with which he has to deal. Only exceptionally should it be necessary for the surgeon to have to interrupt his operation until the pathologist has made a lightning histological examination on the "while-you-wait" system.

The last balf-century has begun a new epoch charac. terized by an ever closer alliance between the basic sciences of physies and chemistry with physiology and pathiflogy. and the eloser application of all of them to the practice of 1 Rev. Wallace Williamson: BrITISH Mrdical JodRnal, 1912,
vol. $i$, p. 444. 
surgery. The chief pioneers of this new era were liocher and Horsley, and for the present stage of its evolution we are indebted to the brilliant researches of such men as Cushing, of Carrel, of Crile, and of Plummer and Kendall of the Mayo clinio-in short, to the American school of surgery.

The problem before surgeons to-day is, "How is this more scientific and enlightened conception of surgery to be encouraged and promoted?" The question is of the greatest importance from the academic point of view. In the first place we must not merely rearrange the time-table of the curriculum; we must also reform and co-ordinate the teaching in such a manner that the student may be shown how to apply his knowledge of the basic sciences to the investigation and treatment of disease-in other words, to his clinical work.

In Edinburgh, in addition to the senior Professor of Ohemistry, we have a second Professor of Chemistry in its relation to medicine, whose teaching is specially adapted to their future requirements, and the same applies to the teaching of physics to the medical students. Botany and zoology must of necessity be taught in the Faculty of Science as separate sciences; it is, how. ever, to be hoped that in the near future the medical student will be given a combined course of animal and vegetable biology, and that the syllabus will be drawn up on such broad and fundamental lines as to ensure that the course will provide him with the best possible foundation for his future studies. It is quite possible that the ideal professor for such a purpose does not exist, and that he will require to be created and specially trained for the purpose. It is a man of the type of the late Professor Huxley that is wanted. It is to be hoped that the teaching of physics and chemistry in the secondary schools will soon reach such a high standard that these subjects may be relegated to the university entrance examination; other. wise the medical curriculum will have to be still further extended.

Edinburgh now as in years past holds the record for undergraduate medical education. While her machinery is specially constructed for this purpose, her 1,800 medical students seriously handicap her in providing facilities for post-graduate clinical work.

It is lack of funds which is sadly crippling us in respect of facilities for original research, and unless the money is forthcoming for the institute we hope to erect as a memorial to Lister, and for which we are at present making an appeal, I am afraid Edinburgh will not be able to pull her full weight. The existing University labora. tories are already heavily taxed with the work necessary to keep up the high standard of undergraduate teaching.

The American College of Surgeons.

The constitution of the American College of Surgeons shows that the best surgeons of America intend to trans late their ideals, their vast energies, their intellect and wisdom into terms of united action for the good both of the guild and of the community. The destiny of the College is in the hands of men who are known throughout the surgical world, men who have travelled and made themselves familiar with the organization of the ancient surgical corporations and the surgical schools of Enrope. They start with a clean slate, unhampered by tradition. True, we have undertaken a gigantic task, such as only Americans would have the courage to venture upon, but when I read the names of the Governors and Regents I am confident that their efforts will be orowned with success No one can sign the pledge of your College without a sense of responsibility being aroused within him. I feel sure, however, that every honest and conscientious surgeon must admit that, in signing it, he is pledging himself to do no more than is his duty to himself, to his profession and to the community.

A point which specially arrested my attention on reading the by-laws was the "interchange of opinion" and "attendance on the important societies and clinics." Surgeons of the individualistic type, who are content to confine themselves to the knowledge gained by their own exclasive experience, can only reach a certain standard of efficiency, and, while it must be admitted that a few reach a high standard, it is safe to say they have done so in spite of their self-sufficiency, and not because of it. That they would have ranked still higher in the surgical world had they been willing to learn from others, everyone will, I think, admit

Perhaps the most striking clause in the laws of the College is the admission to your Fellowship without examination. This departure from precedent was not only justifiable, but, in the circumstances, necessary. Ex. perienced examiners on my own side of the Atlantic have for long felt that the admission of candidates to our Fellow. ship by the methods of examination at present in vogue is open to serious criticism. It by no means follows that because the candidate has passed the examination he is competent to perform major operations. It is to be hoped that the bold, enlightened, and sagacious step which your College has taken will encourage our own, colleges to take further, and possibly similar, precautions to see that candi. dates who obtain our Fellowship are worthy of this dis. tinction. Whether you obtain sufficient evidence that your successful candidate possesses an adequate knowledge of anatomy and pathology is the only criticism I would venture with regard to your present system.

The first impression one might gain after reading the Constitution and By-laws of the American College of Surgeons is that they have been framed in such a way that the governing body is vested with an authority and with disciplinary powers which might be said to interfere somewhat with the liberty of the subject. Even if wo admit that there is a certain amount of truth in this impression, it must be remembered that the profession has a duty, both individually and collectively, not only to its own guild but to the community it serves. It may safely be asserted that in no walk of life, in no other profession, and in no other branch of our profession is the life of the subject so much at the mercy of his fellow-man as when he places himself in the hands of the surgeon. It is only right and proper, therefore, that the profession itself should see to it that a trust so sacred and a weapon so powerful for good or evil, should be placed in the hands of men who have shown that they are morally as well as intellectually and technically capable of fulfilling the trust. In America these powers have been vested in a Council of Regents and an Executive consisting of men of the highest integrity, of great experience, and of poweriul intellect - men who combine great foresight and sagacity with sound judgement, men who can think as able administrators as well as function as great surgeons. Such combined effort is calculated to secure a fine and accurate adjustment of the activities and functions of the surgical profession.

It was the war-a war of science-which brought very forcibly before us what may be accomplished by properly combined and co-ordinated effort fortified by authority and discipline. The peace which has followed has created the opportunity and the necessity for breaking away from tradition, for readjustment, and for reconstruction. phenomenal progress which surgery has made during the present generation and the added knowledge gained through the war has made it all the more imperative that surgery should set its house in order. The surgical world is grateful to America that she has taken the initiative in combining and co-ordinating her surgical forces with the object of raising the general standard of surgery not only in its academic centres but in the hospitals throughout the States. What is needed is co-operative thought transformed into co-operative action. These basic aims have evidently been in the minds of those who drew up the Constitution and By-laws of your College. By vesting the general management of your corporation in a board of fifty governors who shall select fifteen of their number along with the president for the year, to form a Board of Regents in whom shall be vested the details of management, and by choosing from the Board of Regents an executive committee consisting of the president, the secretary, the treasurer, and five other Regents, the College has created a powerful "thought-organization" capable of originating and carrying out an enlightened and far-reaching policy.

The moulding, the development, and the improvement of the standard of hospitals is one of the most importan pieces of organization and propaganda work that your College could undertake. By placing your expert know. ledge and experience at the service of the American Hospital Association you secure a unity of thought and purpose which cannot fail to have great influence upon 
public opinion and ensure the co-operation and sympathy of the municipal authorities as well as open the pursestrings of well-to do citizens. It is important that the lay public be made to see that, after all, the hospital is the surgeon's schoolroom, and the better it is equipped the better will be the training of the surgeon and the better the treatment of the citizen.

Hospital Organization in Britain and America.

The systems of hospital organization in Great Britain and America differ very materially. In my own country all the large teaching horpitals-indeed, the large hospitals generally -are supported almost entirely by voluntary contributions, so that each hospital has its own orguniza. tion and method of administration. There is no attempt at combined effort with a view to standardization, and it cannot be said that we have done anything to enconrage architects to specialize in hospital construction or to create a body of expert hospital superintendents.

Our own hospital system has recently been the subject of a parliamentary inquiry. The Committee has reported in favour of a continuance of the voluntary system, but it is doubtful how long this system will survive under the present burden of taxation. The municipal authorities will certainly be against placing our large hospitals on the rates. While our hospital system is excellent from the point of view of the working classes, it does not meet the requirements of the middle-class population in the way that the American system does; that, however, may I venture to suggest, has two defects which I feel sure the American Hospital Association will be able to remedy without calling in the aid of the State, or, I should say, without the interference of the State. I refer, firstly, to the rotation system of a three or four months' service of general practitioners on the staff of the survical side of hospitals; and, secoudly, to the system whereby facilities are given to practitioners of little or no surgical experience for operating on their private patients in public or semi-public hospitals. These two customs mav in great measure be responsible not only for the relatively jarger amount of surgery done by general practitioners in America, but also for a tendency to the commercialization of surgery.

In my own countiy we : re inclined to go to the other extreme. The want of proper hospital accommodatic $n$ for our middle classes sometimes compels us to operate in patients in their own homes or in imperfectly equipped wuising institutions. While it may occasionally be necessary for a good surgeon to operate unler unfavourable couditions, his conscience ought to dictate that he should only give the patient his second best when it is impossible to do otherwise.

Specialization in surgery should not be discouraged provicted it is preceded by a good general training in surgery. It encourages intensive work in those with special aptitudes; the work itself is better done, and an added zest for it is created. A fin" adinstment of task to individual aptitude is an economy of effort and applies not only to modern surgery but to mudern education generally.

I think I am correct in stating that it is just forty years since the Harvard Medical School instituted a department of orthopaedic surgery, and I am sure my American brethren will be surprised to hear that no such depart ment exists in the Edinburgh Royal Infirmary. Thanks to the genius and magnetic influence of Sir Robert Jones, assisted by a band of orthopaedic experts from America, this brauch of surgery did outstanding work during the war; indeed, it furnished, perhaps, the best example of what may be achieved by able generalship, good organization, and co-ordination of combined effort and team work

It is to be hoped that the lesson to bo learned from the orthopaedic experience and achievements during the way will bear fruit, and that, by the establishment and proper equipment of an orthopaedic department in our teaching centres, the standard of the surgery of the extremities will rapidly improve. We envy America her public spirited citizens who subscribe with such open-handed generosity to every kind of educational institution. The Edinburgh Royal Intirmary, with its 900 beds, which serves not only a uational but an imperial purpose from an educational point of view, and draws its patients not only from Edin. burgh and district, but from a large part of scotland as well as from the north of England, has recently issued an appeal for $£ 250,000$ with the object of meeting the requirements for the teaching and practice of modern medical science. So far the Edinburgh appeal has brought in only $£ 63.000$, all of which will be required to improve and maintain the existing departments. Unfortunately, Scotland is only a small and relatively poor country, with no millionaires, and I am sorry to say the chairman of the Finance Committee, who is fully alive to the necessity of establishing a Chair of Orthopaedics in our great medical school, tells me that it cannot be done-unless some Scotsman who has amassed wealth overseas can be persuaded to come to the rescue.

Already America has done pioneer work in establishing a proper system of preserving and cataloguing case-records. In this way an analysis and review of immediate statistics can from time to time be obtained, and, if the College of Surgeons can help to establish a definite and more standardized follow-up system, such as exists in Boston, Rochester, Baltimore, Cleveland, and elsewhere, statistics of real value will be obtained. In the Edinburgh Royal lnfirmary, while the cases are well "taken," each unit retains its own records, and I regret to say there is no central burean where they are subsequently stored and indexed, so that, up to the present, no attempt has been made to make use of them for statistical purposes. 'This is a serious defect in an institution which has taken such a prominent part in medical education for more than three centuries.

The possibilities which your College affords for organization and prosecuting a systematic, coliective investigation, not only into immediate and end result of operations but also into the value of various other measures employed in surgical therapen:ics, are very great. 'Think, for example, of the benefit which would accrue from a collec. tive investigation into the value of radium and $i$ rays as therapeutic agents in the treatment of malignant disease. With the machinery for organization which your College possesses, the untold wealth of material at its disposal, and the reliable observations which could be guaranteed, I am convinced that in this line of investiga. tion America would again lead the world. Science is ever becoming more and more international. America has taken more adrantage of this cosmopolitan spirit than we Britishers, and in my judgement this is the main $r(a$ ion why the sceptre of surgery is to-day wielded by America.

Brit sh surgeons will, I feel confident, rejoice that you have talien Canada into partuership with you in founding youl: College. The next step, I trust, will be a closer alliance with British surgery. I am thankful to say that at last we have formed an Association of Surgeons of Great Britain and Ireland, having the same ideals and aims as the American Surgical Association, and it is to be hoped that these two bodies will form the beginning of an intimate English-speaking surgical brotherhood which will help to promote every object calculated to advance the progress of the science, the art, and the teaching of surgery, and the relief of human suffering. Science, and especially medical science, recognizes no frontiers; it is the most powerful agent we possess for welding together our two nations-a union which would go far to ensure the peace, happiness, and prosperity of the world.

I cannot do better than conclude with the roords used by Sir Berkeley Moynihan, an Honorary Fellow of you College, who, as you all know, is not only a great surgeon, but is also an inspiring writer and orator: "In presenting you with the mace I see before me," he said, "we pray God may regard it as a symbol of our union in the harsh days of trial, as a pledge of unfaltering and unchanging hope that the members of our profession in the two lands shall be joined in brotherhood for ever in the service of mankind."

THE new buildings of the medical school of the University of Alberta, Canada, have been completed and the equipment transferred to them.

AN Eyesight Conservation Council of America has been incorporated, with headquarters at the limes Building, New York; its objects are to arouse public interest to a proper appreciation of eye hygiene, especially as it pertains to defective vision and protection in hazardous occupations. 